\title{
Comparative Analysis of Tissue and Cell Cycle on the Far Eastern Catfish, Silurus asotus between Diploid and Triploid
}

\author{
Hyun Woo Gil' ${ }^{1}$, Tae Ho Lee' ${ }^{1}$ Ho Jae Han ${ }^{2}$ and 'In-Seok Park ${ }^{1}$ \\ ${ }^{I}$ Division of Marine Bioscience, College of Ocean Science and Technology, Korea Maritime and Ocean University, \\ Busan 49112, Korea \\ ${ }^{2}$ College of Veterinary Medicine and Research Institute of Veterinary Science, Seoul National University, \\ Seoul 08826, Korea
}

\begin{abstract}
The influence of triploidization on histological characteristics of retina, trunk kidney, liver and midgut tissue, and cell cycle of tail fin and gill tissue in far eastern catfish, Silurus asotus were analyzed. In the infertile triploid fish, the nucleus and/or cell size of secondary proximal tubule cells of trunk kidney, hepatocyte and midgut epithelium are much larger than those of the corresponding cells in the diploid fish $(P<0.05)$. However, triploid tissue showed fewer number of outer nuclear layer in retina and nuclei in secondary proximal tubule of trunk kidney than those for diploid tissue. The mean percentages of the $\mathrm{Gl}_{1}$, the $\mathrm{S}$ - and the $\mathrm{G}_{2}+\mathrm{M}$-phase fractions were $92.5 \%, 3.2 \%$ and $4.3 \%$ in tail fin tissue of diploid, and $93.4 \%, 2.6 \%$ and $4.0 \%$ in those of triploid, respectively. There were no significant differences in the percentages of each cell cycle fraction between diploid and triploid. The mean percentages of each phase fractions were $75.1 \%, 11.1 \%$ and $13.8 \%$ in gill tissue of diploid and $85.2 \%, 8.9 \%$ and $5.9 \%$ in those of triploid, respectively. The differences of cell cycle between tail fin tissue and gill tissue were statistically significant in diploid and triploid $(P<0.05)$. Also, the differences between diploid and triploid were statistically significant in tail fin tissue and gill tissue $(P<0.05)$. Cyclin D1 and cyclin E expressions were not significantly difference between gill tissue and tail fin tissue, and protein expressions of induced triploid were higher than those of diploid. Results from this study suggest that some characteristics in the triploid exhibiting larger cell and nucleus size with fewer number of cell than diploid can be used as an indicator in the identification of triploidization and ploidy level in far eastern catfish.
\end{abstract}

Key words : Diploid, Triploid, Cell and nucleus size, Cell cycle, Protein expression, Silurus asotus

\section{INTRODUCTION}

The far eastern catfish, Silurus asotus (Linnaeus, 1758) (family Siluridae), is distributed widely throughout Northeast Asia and is an important food-fish species in the Korean freshwater aquaculture industry (Kim et al., 2001; Yang et al., 2015). However, there are two major issues in the culturing of this species. Firstly, they exhibit a sex- specific dimorphism in growth rate, which allow females to grow much faster than males (Kim et al., 2001). This sex-specific growth difference leads to difficultly in effective stock management and also frequently results in severe cannibalism in farms during the early stages of life (Kim et al., 2001). Secondly, the early maturation prior to the fish reaching marketable size necessitates an extended cultivation period beyond sexual maturity. Upon attaining

\footnotetext{
Manuscript received May 16, 2017, Received in revised form May 20, 2017, Accepted May 24, 2017

${ }^{\dagger}$ Corresponding Author : In-Seok Park, Division of Marine Bioscience, College of Ocean Science and Technology, Korea Maritime and Ocean University, Busan 49112, Korea, Tel : +82-51-410-4321, Fax : +82-51-405-4322, E-mail : ispark@kmou.ac.kr

This is an Open Access article distributed under the terms of the Creative Commons Attribution Non-Commercial License (http:// creativecommons.org/licenses/by-nc/3.0) which permits unrestricted non-commercial use, distribution, and reproduction in any medium, provided the original work is properly cited.
} 
sexual maturity the fish begin to experience reduced growth and decreased feed efficiency (Choi et al., 1992).

In the far eastern catfish farming industry, chromosomeengineering techniques have been applied using genetics and breeding methods to improve productivity. Preliminary studies on this species have addressed the temperaturedependent somatic cell division cycle $\left(\tau_{0}\right)$, nuclear division of the egg, gonadogenesis, and the cytogenetic production of gynogenetically diploid, all-female diploid, and triploid strains (Kim et al., 2001; Park et al., 2004). In particular, the induction of triploid, sterile catfish by a chromosomeengineering technique is drawing attention as a way to enhance the productivity of fish farming per unit effort in the short term (Thorgaard, 1986; Cassani et al., 1990). Production of infertile fish, either through direct triploidization induction or by breeding tetraploid females with diploid males, is widely practiced in aquaculture and has been shown to produce fish which exhibit improved survival and extended growth (Hulata, 2001).

Triploidization is a technique used to generate sterile aquatic animals by taking advantage of the incompatibility in pairing the three homologous chromosomes during meiosis I (Don \& Avtalion, 1986). This technique has also been used to enhance the productivity of several fish species because of its assumed ability to increase yield by channeling the energy required from gonadal development to somatic growth (Tave, 1993). More importantly, it generates fish that are unable to breed and contribute to the local gene pool if they were to accidentally escape from confinement. By conferring sterility of exotic fish for a limited purpose, triploidy can serve as an effective method for reducing or eliminating the environmental risks of genetically modified organisms (Kim et al., 1994; Murray et al., 1999). Triploidy was confirmed by the 1.5 -fold increase in nuclear volume, cellular DNA content and chromosome number as estimated by erythrocyte counting, respectively (Seol et al., 2008). Fraction of NORs of different ploidy levels of far eastern catfish was also well coincided with the previous study on triploid salmonid (Phillips et al., 1986).

There are numerous studies in the literature which have investigated various aspects of triploid fish identification methodology including analysis of chromosome sets (Thorgaard, 1986), the microfluorimetry of nuclear DNA content (Komaru et al., 1988), the nuclear DNA content by flowcytometry (Allen \& Stanley, 1978), the measurement of erythrocyte and nuclear size (Thorgaard, 1986; Kim et al., 1990; Park \& Kim, 1994; Park et al., 1994), the distinction of nucleolar number (Philips et al., 1986), the measurement of cell number (Ueno, 1984; Park \& Park, 1994), and the measurement of cell and nuclear size in different tissues (Swarup, 1959; Aliah et al., 1990). Park \& Kim (2000) reported that characteristics of the some tissues of retina, optic tectum and trunk kidney in triploid and diploid hybrid between female mud loach, Misgurnus mizolepis and male cyprinid loach, M. andguillicaudatus.

Flow cytometry has a wide variety of clinical applications in oncology for understanding surface expression, intracellular signaling, cell cycle content analysis, and a number of other interesting parameters (Vanparys et al., 2006). Recent advances in instrument platforms, calibration methods, and reagent quality have now made flowcytometry a promising tool for DNA content analysis (Estevam et al., 2011). These calibration packages can detect if the parameters are within acceptable ranges and thus allow for consistent sample acquisition over time. One of the advantages of flowcytometry is the rapidity of the measurement, making it possible to measure thousands of cells over a short period of time, and the ability for multicolor immunophenotyping (Estevam et al., 2011).

However, for cell cycle analysis by flowcytometry, care should be taken to collect cells at a proper rate. In order to yield a good signal in $\mathrm{G}_{2} / \mathrm{M}$ and to discriminate between singlets and doublets, samples should be analyzed at rates below 1,000 cells per second (Nunez, 2001). Samples processed through the cell cycle assay described were ana- 
lyzed below this cellular threshold rate. Since the data obtained is not a direct measure of the cellular DNA content, reference cells, such as human leukocytes or red blood cells from chicken or trout should be used (Nunez, 2001). Incorporation of these reference standards can be used to determine the position of cells with a normal diploid amount of DNA and thus allows for a more consistent interpretation of the data (Estevam et al., 2011).

The aim of this study is to conduct a comparative histological analysis of retina, kidney, liver and midgut tissue by looking at cellular and nuclear size, and conduct a comparative analysis of cell cycle from tissues of diploid and triploid far eastern catfish.

\section{MATERIALS AND METHODS}

Triploid far eastern catfish, Silurus asotus induction was carried out in accordance with the methods of Kim et al. (2001) and Seol et al. (2008). Mature females were induced to spawn using a single intraperitoneal (IP) injection of human chorionic gonadotropin (hCG, Sigma, USA) administered at 1,000 IU per $\mathrm{kg}$ body weight $(\mathrm{kg} / \mathrm{BW})$. Sperm was obtained by incision of surgically removed testes that had also been given an IP injection of hCG at $500 \mathrm{IU} \mathrm{kg} / \mathrm{BW}$. Eggs were fertilized with sperm diluted in saline using the wet method (Kim et al., 2001; Seol et al., 2008). The eggs were left to fertilize for 5 mins after which they were rapidly rinsed to remove excess sperm and immediately subjected to cold-shock treatment $\left(4^{\circ} \mathrm{C}\right)$ for 60 mins in order to prevent the onset of the second polar body. Untreated fertilized eggs were used as diploid controls.

Flow cytometric analysis was performed to estimate the average celluar DNA content of 10 individuals from diploid and triploid far eastern catfish. After anesthetizing the fish with $200 \mathrm{ppm}$ lidocaine- $\mathrm{HCl} / 1,000 \mathrm{ppm} \mathrm{NaHCO}_{3}$, a $0.5 \sim 1.0 \mathrm{~mL}$ sample of whole blood was collected from the caudal vein of each of 10 individuals. Blood cells were fixed in $10 \mathrm{~mL}$ of cold $70 \%$ ethanol and filtered through a
$30 \mu \mathrm{m}$ filter. The cell solution was stored at $4^{\circ} \mathrm{C}$. One million cells were collected and stained using a high-resolution DNA staining kit (Partec GmbH, Germany) under dark conditions at room temperature for 15 mins. Stained samples were analyzed on Partec PA-II flowcytometer (Partec GmbH, Germany) to determine the relative DNA content. The red blood cells ( $2.8 \mathrm{pg}$ DNA/nucleus) of mud loach Musgurnus mizolepis were used as a standard reference (Park et al., 1999). Partec PA-II flowcytometer calculates the percentage of cells in $\mathrm{G}_{1^{-}}, \mathrm{S}-$ and $\mathrm{G}_{2}+\mathrm{M}$-phase fractions in the diploid cell population and in the triploid cell population. The differences among groups were analyzed using Student's $t$-test from the SPSS statistics package (SPSS 9.0, SPSS Inc. Chicago, IL, USA).

Specimens were sourced from 1 year hatchlings which had an average body mass of $302.1 \pm 15.22 \mathrm{~g}$ (mean \pm S.D.) and a standard length of $31.5 \pm 4.19 \mathrm{~cm}$ (mean \pm S.D.). Ten specimens were used for histological observations from each group. Fish were euthanized with an overdose of lidocaine- $\mathrm{HCl}\left(300 \mathrm{ppm}\right.$ at $22^{\circ} \mathrm{C}$, Park et al., 1998) and immediately dissected on an ice-cold cutting board. The retina, kidney, liver and midgut epithelium were removed and extracted tissue samples fixed in $10 \%$ neutral formalin solution (100 mL formalin, $6.5 \mathrm{~g} \mathrm{Na}_{2} \mathrm{HPO}_{4} \cdot 12 \mathrm{H}_{2} \mathrm{O}, 4.5 \mathrm{~g}$ $\mathrm{KH}_{2} \mathrm{PO}_{4}, 900 \mathrm{~mL} \mathrm{DW}$ ) for $24 \mathrm{hrs}$. The samples were then refixed in Bouin's solution for a further $24 \mathrm{hrs}$. All fixed tissues were routinely dehydrated in ethanol, equilibrated in xylene and embedded in paraffin according to standard histological techniques. Transverse sections were then cut at $6 \mu \mathrm{m}$ and routinely stained using Mayers' Haematoxlyin and eosin Y-phroxine $\mathrm{B}$ before being observed under a high-powered microscope (Carl Zeiss, Germany).

The Axioskop 4.1image analysis software (Carl Zeiss, Germany) was employed to measure area and volume of cells and nuclei using the following formulas: Surface area $=1 / 4 \times \mathrm{ab} \pi$ and Volume $=4 / 3 \times \pi(\mathrm{a} / 2) \times(\mathrm{b} / 2)^{2}($ Where: $\mathrm{a}=$ the major axis of a cell or nucleus; $b=$ the minor axis of $a$ cell or nucleus). 
For western blots, tail fin and gill tissue were extracted from diploid and induced triploid far eastern catfish, and mixed with lysis buffer (40 mM Tris, $120 \mathrm{nM} \mathrm{NaCl}, 1 \mathrm{mM}$ phenylmethylsulfonyl fluoride, $10 \mathrm{mg} / \mu \mathrm{L}$ leupeptin, $2 \mathrm{mM}$ sodium orthovanadate, $10 \mu \mathrm{g} / \mathrm{mL}$ aprotinin). Samples were homogenized by homogenizer prior to centrifugation (Centrifuge Micro 17R, Hanil Science Industrial Co., Ltd, Incheon, Korea) for 20 mins at $12,000 \mathrm{rpm}$, and subjected to sodium dodecyl sulfate-polyacrylamide gel electrophoresis (10\% SDS-PAGE) and electrotransfer. Extracted protein was transferred to nitrocellulose membrane for $2 \mathrm{hrs}$ at 80 $\mathrm{V}$. To prevent a non-specific response, blocking reaction in room temperature was executed using $5 \%$ nonfat milk for $1 \mathrm{hr}$, and treated with a HRP-conjugated anti-rabbit, goat IgG (1:10,000; Santa Cruz Biotechnology, USA) and ECL detection Kit (Amersham Pharmacia Biotech, England, UK). After 20 days, for comparing protein expression of cell cycle adjustment protein along organized damage, regeneration site of tail fin and gill tissue were extracted from diploid and induced triploid far eastern catfish, and were analyzed with western blot analysis. The differences among groups were analyzed using Student's $t$-test from the SPSS statistics package (SPSS 9.0, SPSS Inc. Chicago, IL, USA).

\section{RESULTS}

Structure of the retina in triploid far eastern catfish, $\mathrm{Si}$ lurus asotus were the same as those in the diploid, analyzed from seven distinct component layers; pigment epithelium and bacillary layer, outer nuclear layer, outer plexible layer, inner plexible layer, ganglion cell layer, optic nerve fiber layer and inner limiting membrane (Fig. 1a and Fig. 1b). The thickness (\%) of each layer in both triploids and diploid fish is shown in Table 1. Statistically significant differences in thickness was found in the outer nuclear layer, outer plexible layer, inner plexible layer and pigment epithelium and bacillary layer ( $t$-test, $n=12$, d.f. $=239$, $P<0.05)$ between the two tissue types. In the former four
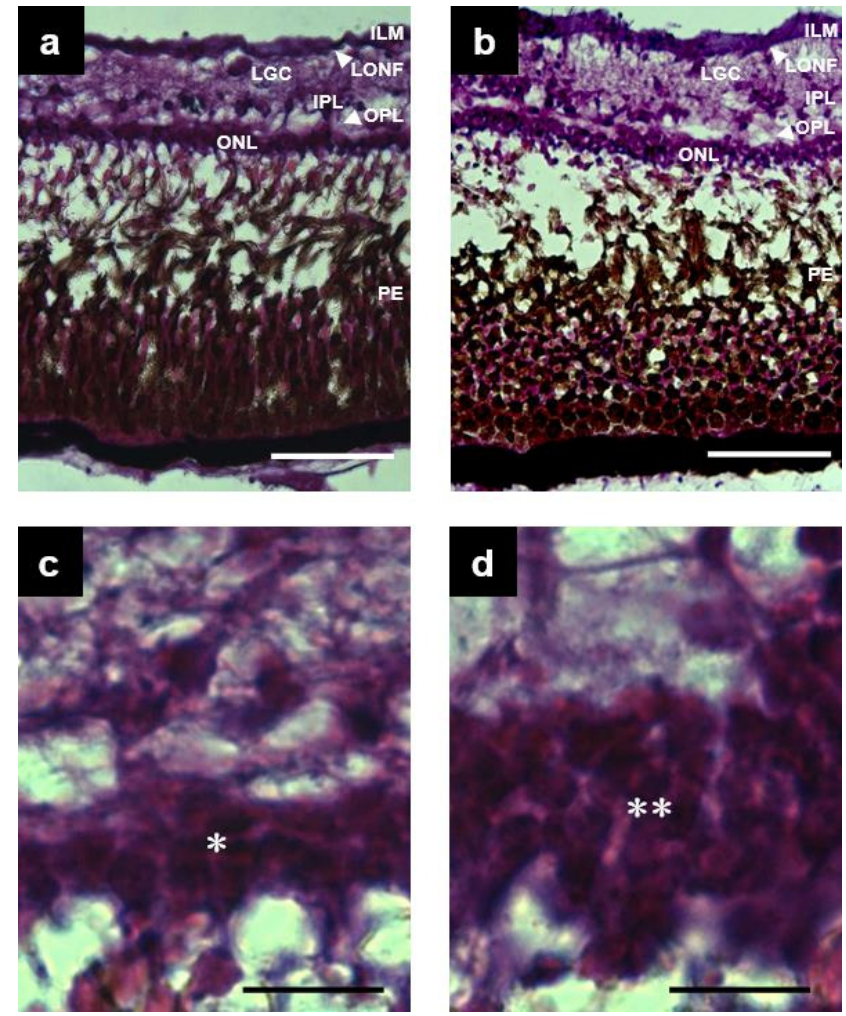

Fig. 1. Retina of diploid and triploid in far eastern catfish, Silurus asotus. (a) layer of retina of diploid, bar is $50 \mu \mathrm{m}$; (b) layer of retina of triploid, bar is 50 $\mu \mathrm{m}$; (c) outer layer cell nucleus $(* 1)$ of diploid retina, bar is $10 \mu \mathrm{m}$; (d) outer layer cell nucleus $(* 2)$ of triploid retina, bar is $10 \mu \mathrm{m}$. Abbr. ILM, inner limiting membrane; ONF, layer of optic nerve fibers; LGC, layer of ganaglion cell; IPL, inner plexibel layer; OPL, outer plexible layer; ONL, outer nuclear layer; PE, pigment cell and bacillary layer.

layers, the diploids showed larger values than the triploids. There was also a difference in cellular structure between triploids and diploids. In triploids, the outer nuclear layer consisted of two strata of nuclei (Fig. 1c), while in diploids the same layer consisted of three strata of nuclei (Fig. 1d).

The size and area of the secondary proximal tubule cell of the trunk kidney of triploid and diploid far eastern catfish and the size, area and number of nuclei in the secondary proximal tubule of the trunk kidney were compared. In relation to secondary proximal tubule cell size and area diploids were significantly larger than triploids ( $t$-test, $n=$ 
12 , d.f. $=239, P<0.05)$. In relation to size, area and volume

of nucleus they were also significantly larger than triploid
( $t$-test, $n=12$, d.f. $=239, P<0.05)$ (Table 2). However, the number of nuclei within the secondary proximal tubule of

Table 1. Thickness in each component layer and the number of outer nuclear layer of retina in diploid and triploid far eastern catfish, Silurus asotus

\begin{tabular}{|c|c|c|c|}
\hline & Diploid & Triploid & Ratio" \\
\hline Thickness of retina $(\mu \mathrm{m})^{* *}$ & $251.79 \pm 10.216^{\mathrm{a}}$ & $246.68 \pm 10.639^{\mathrm{a}}$ & 0.98 \\
\hline \multicolumn{4}{|l|}{ Thickness of each layer of retina $(\%)^{* *}$} \\
\hline Inner limiting membrane (ILM) & $4.05 \pm 0.549^{\mathrm{a}}$ & $4.31 \pm 0.303^{\mathrm{a}}$ & 1.06 \\
\hline Layer of optic nerve fibers (ONF) & $3.75 \pm 0.312^{\mathrm{a}}$ & $3.45 \pm 0.164^{\mathrm{a}}$ & 0.92 \\
\hline Layer of ganglion cell (LGC) & $7.99 \pm 0.598^{\mathrm{a}}$ & $8.25 \pm 0.604^{\mathrm{a}}$ & 1.03 \\
\hline Inner plexible layer (IPL) & $6.28 \pm 0.698^{b}$ & $5.54 \pm 0.569^{\mathrm{a}}$ & 0.88 \\
\hline Outer plexible layer (OPL) & $5.60 \pm 0.205^{\mathrm{b}}$ & $4.76 \pm 0.587^{\mathrm{a}}$ & 0.85 \\
\hline Outer nuclear layer $(\mathrm{ONL})$ & $8.21 \pm 0.642^{\mathrm{b}}$ & $6.89 \pm 0.463^{\mathrm{a}}$ & 0.84 \\
\hline Pigment epithelium and bacillary layer (PE) & $70.28 \pm 8.687^{\mathrm{b}}$ & $63.92 \pm 7.003^{\mathrm{a}}$ & 0.91 \\
\hline Number of outer nuclear layers in retina & 3 & 2 & 1.50 \\
\hline
\end{tabular}

${ }^{*}$ Triploid/diploid.

${ }^{* *}$ Values are means $\pm \mathrm{SD}$. Values in same row having the different superscripts are significantly different $(P<0.05)$.

Table 2. Cell and nuclear size of secondary proximal tubule of trunk kidney and its nuclear number in diploid and triploid far eastern catfish, Silurus asotus

\begin{tabular}{lccc}
\hline \hline & Diploid & Triploid & Ratio* $^{*}$ \\
\hline Secondary proximal tubule cell of trunk kidney $^{* *}$ & & & \\
Major axis $(\mu \mathrm{m})$ & $10.34 \pm 1.178^{\mathrm{a}}$ & $12.19 \pm 1.375^{\mathrm{b}}$ & 1.18 \\
Minor axis $(\mu \mathrm{m})$ & $8.33 \pm 7.706^{\mathrm{a}}$ & $9.72 \pm 8.222^{\mathrm{b}}$ & 1.67 \\
Surface area $\left(\mu \mathrm{m}^{2}\right)$ & $64.67 \pm 6.275^{\mathrm{a}}$ & $90.35 \pm 9.978^{\mathrm{b}}$ & 1.40 \\
\hline Secondary proximal tubule nucleus of trunk kidney ${ }^{* *}$ & & & 1.26 \\
Major axis $(\mu \mathrm{m})$ & $3.26 \pm 0.328^{\mathrm{a}}$ & $4.11 \pm 0.420^{\mathrm{b}}$ & 1.14 \\
Minor axis $(\mu \mathrm{m})$ & $3.01 \pm 0.397^{\mathrm{a}}$ & $3.42 \pm 0.307^{\mathrm{b}}$ & 1.43 \\
Surface area $\left(\mu \mathrm{m}^{2}\right)$ & $7.70 \pm 0.755^{\mathrm{a}}$ & $11.01 \pm 8.181^{\mathrm{b}}$ & 1.85 \\
Volume $\left(\mu \mathrm{m}^{3}\right)$ & $14.64 \pm 7.658^{\mathrm{a}}$ & $27.05 \pm 2.106^{\mathrm{b}}$ & 0.63 \\
Nucleus number in secondary proximal tubule & $15.70 \pm 2.080^{\mathrm{b}}$ & $9.80 \pm 1.111^{\mathrm{a}}$ & \\
\hline
\end{tabular}

\footnotetext{
${ }^{*}$ Triploid/diploid.
}

${ }^{* *}$ Values are means $\pm \mathrm{SD}$. Values in same row having the different superscripts are significantly different $(P<0.05)$. 
trunk kidney was higher in diploids then triploids ( $t$-test, $n$ $=12$, d.f. $=239, P<0.05$ ) (Fig. 2a and Fig. 2b).

Table 3 shows the comparison of hepatocyte nuclear area and nuclear height of midgut epithelium between diploids and triploids samples. The hepatocyte nuclear area was 1.25 times larger ( $t$-test, $n=12$, d.f. $=239, P<0.05)$ in triploids (Fig. 2c and d), while the nuclear height of midgut epithelium was $9.91 \pm 0.797 \mu \mathrm{m}^{2}$ (mean \pm S.D.) in diploids and $12.27 \pm 0.785 \mu \mathrm{m}^{2}$ (mean \pm S.D.) in triploids,
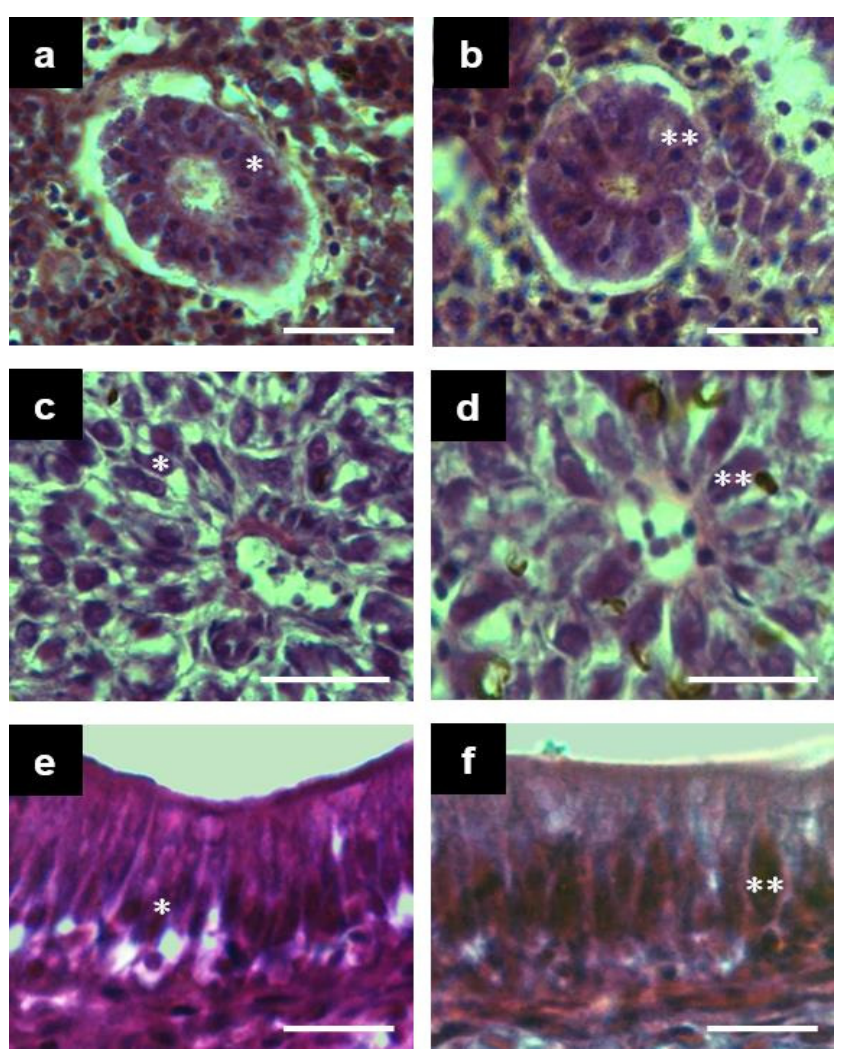

Fig. 2. Comparison of secondary proximal tubule nuclei of trunk kidney, hepatocyte nuclear area and nuclear height of midgud epithelium in diploid and triploid far eastern catfish, Silurus asotus. (a) secondary proximal tubule nucleus of diploid trunk kidney $(* 1)$, bar is $10 \mu \mathrm{m}$; (b) secondary proximal tubule nucleus of triploid trunk kidney $(* 2)$, bar is $10 \mu \mathrm{m}$; (c) hepatocyte of diploid (*1), bar is $5 \mu \mathrm{m}$; $\mathrm{d}$, hapatocyte of triploid (*2), bar is $5 \mu \mathrm{m}$; e, midgut epithelium of diploid (*1), bar is $10 \mu \mathrm{m}$; $\mathrm{f}$, midgut epithelium of triploid, bar is $10 \mu \mathrm{m}$. with triploid fish being 1.24 times larger than diploids (Fig. 2e and Fig. 2f).

Fig. 3 shows a DNA histogram of diploid far eastern catfish with tail fin tissue and gill tissue generated by the software package. This histogram contains the $\mathrm{G}_{1}$-peak, the S-phase region and $\mathrm{G}_{2}+\mathrm{M}$-peak with the background correction. The percentages of the $\mathrm{G}_{-}^{-}$, the $\mathrm{S}-$ and the $\mathrm{G}_{2}+\mathrm{M}-$ phase fractions were $95.8 \%, 1.2 \%$ and $3.0 \%$ in the tail fin tissue and $75.1 \%, 11.2 \%$ and $13.7 \%$ in the gill tissue, respectively (Fig. 3a and Fig. 3b). Fig. 4 represents the histogram of triploid far eastern catfish with tail fin tissue and gill tissue. The percentages of the $\mathrm{G}_{1}^{-}$, the $\mathrm{S}$ - and the $\mathrm{G}_{2}+\mathrm{M}$-phase fractions were $97.4 \%, 0.6 \%$ and $2.0 \%$ in the tail fin tissue cells and $85.2 \%, 8.9 \%$ and $5.9 \%$ in the gill tissue cells, respectively (Fig. 4a and Fig. 4b).

The mean percentages of the $\mathrm{G}_{1}-$, the $\mathrm{S}-$ and the $\mathrm{G}_{2}+\mathrm{M}$ -

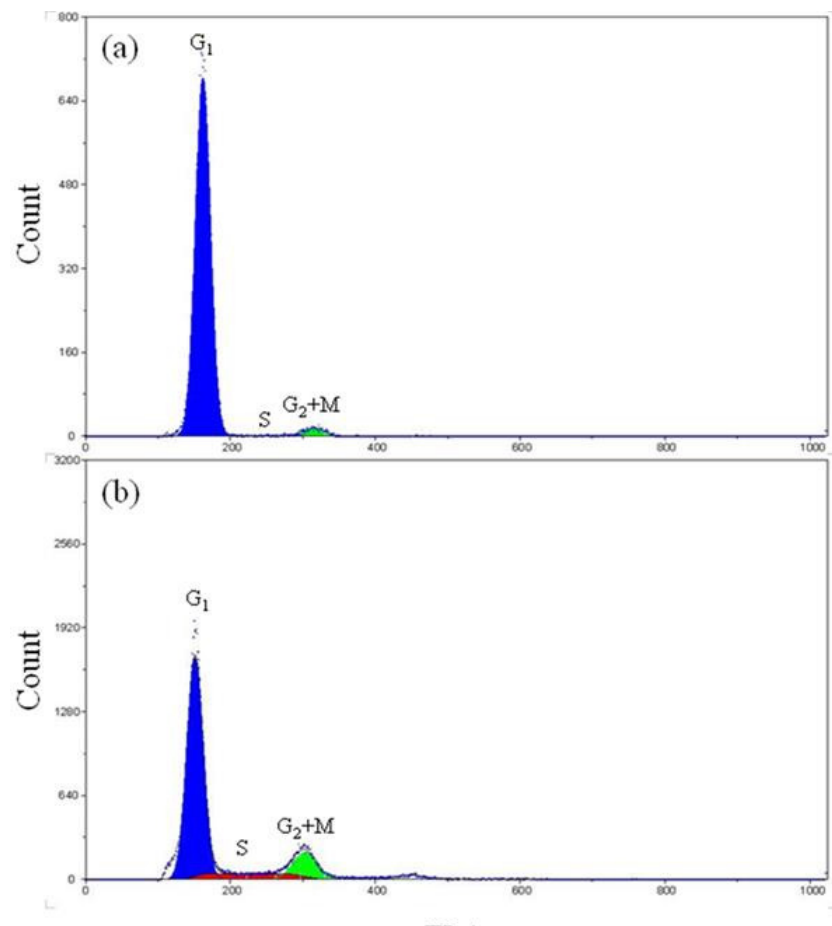

FL4

Fig. 3. DNA histogram of diploid far eastern catfish, Silurus asotus in tail fin tissue and gill tissue. (a): tail fin tissue; (b): gill tissue. Each cell cycle fraction with background correction is indicated. Fluorescence 4 (FL4) is ray of red light. 
Table. 3 Comparison of hepatocyte nuclear and nuclear height of midgut epithelium in diploid and triploid far eastern catfish, Silurus asotus

\begin{tabular}{lccc}
\hline \hline & Diploid & Triploid & Ratio $^{*}$ \\
\hline Hepatocyte nuclear area $\left(\mu \mathrm{m}^{2}\right)^{* *}$ & $10.77 \pm 0.643^{\mathrm{a}}$ & $13.41 \pm 1.210^{\mathrm{b}}$ & 1.25 \\
Nuclear height of midgut epithelium $(\mu \mathrm{m})^{* *}$ & $9.91 \pm 0.797^{\mathrm{a}}$ & $12.27 \pm 0.785^{\mathrm{b}}$ & 1.24 \\
\hline
\end{tabular}

${ }^{*}$ Triploid/diploid.

${ }^{* *}$ Values are means $\pm \mathrm{SD}$. Values in same row having the different superscripts are significantly different $(P<0.05)$.

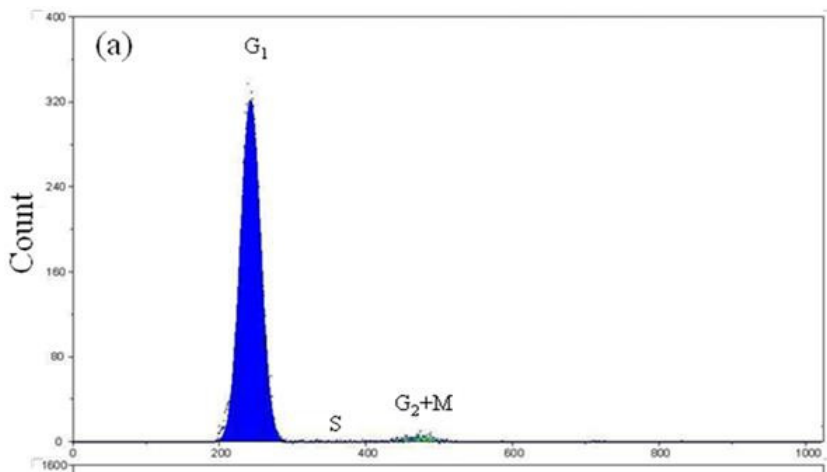

(b)

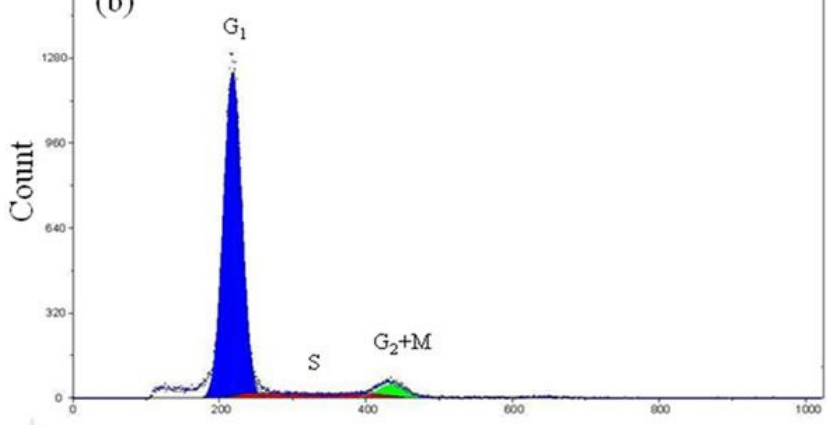

FL4

Fig. 4. DNA histogram of triploid far eastern catfish, Silurus asotus in tail fin tissue and gill tissue. (a): tail fin tissue; (b): gill tissue. Each cell cycle fraction with background correction is indicated. Fluorescence 4 (FL4) is ray of red light.

phase fractions were $92.5 \%, 3.2 \%$ and $4.3 \%$ in tail fin tissue of diploid, and $93.4 \%, 2.6 \%$ and $4.0 \%$ in those of triploid, respectively (Table 4). There were no significant differences in the percentages of each cell cycle fraction be tween diploid and triploid. Nor were there any significant differences in the percentages of each cell cycle fraction between the diploid and the triploid of the tail fin tissue. However, the S- and $\mathrm{G}_{2}+\mathrm{M}$-phase fraction of diploid was higher than those of triploid, although those differences were not statistically significant (Table 4). On the other hand, the mean percentages of the $\mathrm{G}_{1}^{-}$, the $\mathrm{S}$ - and the $\mathrm{G}_{2}+\mathrm{M}$-phase fractions between diploid and triploid had shown significantly difference in gill tissue $(P<0.05)$, and the mean percentages of each phase fractions were $75.1 \%$, $11.1 \%$ and $13.8 \%$ in gill tissue of diploid and $85.2 \%, 8.9 \%$ and $5.9 \%$ in those of triploid, respectively (Table 4). The differences of cell cycle between tail fin tissue and gill tissue were statistically significant in diploid and triploid far eastern catfish $(P<0.05)$. Also, the differences between diploid and triploid far eastern catfish were statistically significant in tail fin tissue and gill tissue $(P<0.05)$.

Fig. 5 shows protein expression of cyclin D1 and cyclin E through western blot anlysis at diploid and induced triploid far eastern catfish to compare protein expression of cell cycle adjustment protein along organized damage. Regenerating site's length of gill tissue and tail fin tissue was 2-3 mm while 20 days. Cyclin D1 and cyclin E expressions after organized damage were lower than those before organized damage in both tissues of diploid and induced triploid far eastern catfish, respectively. In all experimental groups, protein expressions of induced triploid were higher than those of diploid. Significant difference of Cyclin D1 and cyclin E expressions were not determined between gill tissue and tail fin tissue. In tail fin tissue, cyclin 
HW Gil, TH Lee, HJ Han, I-S Park

Table 4. Relationship of cell fraction among ploidy and tissue in far eastern catfish, Silurus asotus

\begin{tabular}{cccccccc}
\hline \hline \multirow{2}{*}{$\begin{array}{c}\text { Mean fraction } \\
\text { percentage (\%) }\end{array}$} & \multicolumn{3}{c}{ Diploid $^{*}$} & & \multicolumn{3}{c}{ Triploid* $^{*}$} \\
\cline { 2 - 4 } \cline { 7 - 9 } & $\mathrm{G}_{1}$ & $\mathrm{~S}$ & $\mathrm{G}_{2}+\mathrm{M}$ & & $\mathrm{G}_{1}$ & $\mathrm{~S}$ & $\mathrm{G}_{2}+\mathrm{M}$ \\
\hline Tail fin & $92.5 \pm 5.58^{\mathrm{a}}$ & $3.2 \pm 0.71^{\mathrm{a}}$ & $4.3 \pm 0.87^{\mathrm{a}}$ & & $93.4 \pm 5.71^{\mathrm{a}}$ & $2.6 \pm 0.74^{\mathrm{a}}$ & $4.0 \pm 1.05^{\mathrm{a}}$ \\
Gill & $75.1 \pm 3.69^{\mathrm{b}}$ & $11.1 \pm 2.66^{\mathrm{b}}$ & $13.8 \pm 3.52^{\mathrm{b}}$ & & $85.2 \pm 5.98^{\mathrm{b}}$ & $8.9 \pm 0.58^{\mathrm{b}}$ & $5.9 \pm 1.51^{\mathrm{b}}$ \\
\hline
\end{tabular}

${ }^{*}$ Values are means $\pm \mathrm{SD}$. Values in same row having the different superscripts are significantly different $(P<0.05)$.

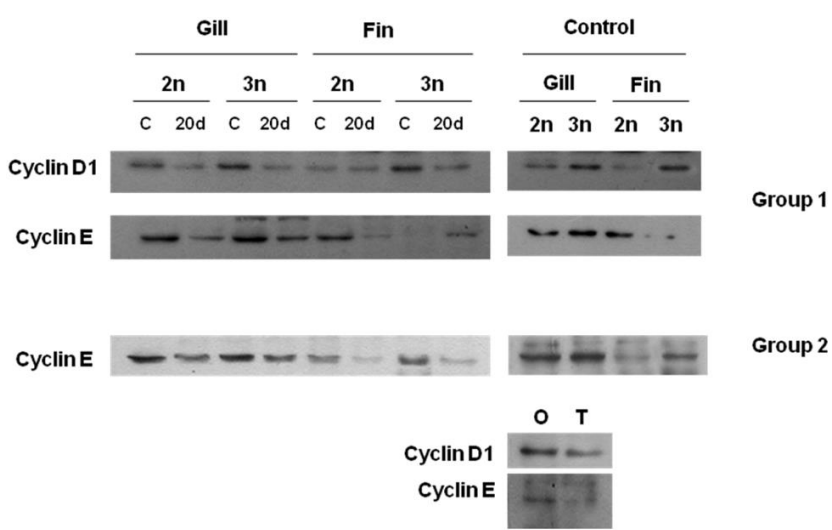

Fig. 5. Protein expression of cyclin $D 1$ and cyclin $E$ through western blot anlysis at diploid and induced triploid far eastern catfish, Silurus asotus. C: control, tissue before organized damage; $20 \mathrm{~d}$ : tissue at 20 days after organized damage; O: origin part of tail fin; $\mathrm{T}$ : terminal part of tail fin.

D1 and cyclin E expressions of origin part were higher than those of terminal part.

\section{DISCUSSION}

There are a number of techniques for separating diploid and induced triploid far eastern catfish, Silurus asotus. The three most widely accepted methods now used are flow cytometric measurements of erythrocyte DNA (Thorgaard et al., 1982), Coulter counter estimation of erythrocyte nuclear size (Thorgaard et al., 1982), and measurement of erythrocyte nuclear volume by light microscopy (Wolters et al., 1982). Unfortunately, the first two methods are very expensive, and light microscopy is time-consuming and insufficiently accurate for widespread use. Clearly, any method that would be as accurate as, more rapid, and less costly than these three techniques would be helpful to far eastern catfish culturists. So, flowcytometry was used in this study for determine success of induced triploid's induction and cell cycle of diploid and induced triploid.

Our analysis of the retinal tissue provided similar structural characteristics to that of carps (Takashi, 1982, Park \& Kim, 2000). The outer nuclear layer of the retina consisted of three strata of nuclei in diploids and two strata in triploid fish. Consequently the diploid nuclear layers were thicker. It is generally accepted that nuclear size increases in proportion with chromosome number (Alaih et al., 1990). The number of nuclei in diploid visual cells (cells of pigment epithelium and bacillary layer) are therefore larger resulting in higher cell density. This fact suggests that diploids possess higher acuity of vision than triploids. This phenomenon has also been observed in triploid ayu, Plecoglossus altivelis and triploid hybrid between mud loach, Misgurnus mizolepis and cyprinid loach, M. anguillicaudatus (Park \& Kim, 2000).

Swarup (1959) reported that the number of cells of the pronephric duct of the Three-spined stickleback Gasterosteus aculeatus was 26 in the diploid and 18 in the triploid, while Aliah et al. (1990) reported that the secondary proximal tubule of the trunk kidney in ayu contained 9 nuclei in diploids and 6 nuclei in triploids. In this study the size of secondary proximal tubule of trunk kidney was $15.7 \pm$ 2.08 nuclei in diploids and $9.8 \pm 1.11$ nuclei in triploids, proving to be similar to previous studies (Aliah et al., 1990; Park \& Kim, 2000). Our investigations also revealed the 
hepatocyte nuclear area height of midgut epithelium to be larger in triploids than in diploid indicating larger chromosome numbers. Nevertheless, the reason why this condition doesn't cause giantism is due to the inevitable tradeoff where larger cell size results in lower total cell numbers (Ueno, 1984; Aliah et al., 1990; Park \& Kim 2000).

A consequence of triploidy is the increase of nuclear size because of the higher number of chromosomes. In addition, the maintenance of the nucleo-cytoplasmic ratio implies that, in triploids, the cells of most of the organs (brain, retina, kidney, liver, testis and ovaries) and tissues (blood, cartilages, muscles and epithelia) are larger than those of their diploid counterparts (Benfey, 1999). On the other hand, the organs and tissues of triploid individuals appear to have a reduced number of cells compared with diploids so that the entire size remains alike that of a diploid fish (Maxime, 2008; Tiwary et al., 2004). The triploid and diploid characteristics identified in our study are identical to other similar comparative studies (Aliah et al., 1990; Park \& Kim, 2000). Seol et al. (2008) reported that haematological parameters and respiratory function in diploid and induced triploid of the far eastern catfish. The results of Seol et al. (2008) showed an increase in erythrocyte size in induced triploids, in agreement with the previously reported increase in the cell volumes of polyploidy animals (Benfey, 1999). In teleost fish, the increase in erythrocyte size associated with induced triploidy has already been reported and the measurment of red blood cell dimensions was proposed as a rapid and inexpensive assay for induced triploidy (Ueno, 1984; Benfey, 1999). The increase in erythrocyte nuclear size in induced triploids is a consequence of their higher DNA content (Benfey, 1999).

As mentioned Seol et al. (2008), the haematocrit value, total haemoglobin content, and mean corpuscular haemoglobin concentration were not significantly different between diploid and induced triploid far eastern catfish, but the erythrocyte size, erythrocyte count, mean corpuscular volume, and mean corpuscular haemoglobin were in- creased in induced triploid catfish. This increase in cellular size was offset by a decrease in cell number, which explains the lack of a difference in haematocrit observed between diploid and induced triploid far eastern catfish, as reported in other fish species (Benfey, 1999; Seol et al., 2008). The relationship between oxygen consumption and respiratory frequency was higher in induced triploids than in diploids, although diploid and induced triploid far eastern catfish showed similar oxygen consumption (Seol et al., 2008). Therefore, the lower oxygen capability of induced triploid is in agreement with the haematological characteristics of induced triploid far eastern catfish (Seol et al., 2008).

In this study, mitosis of diploid in each tissue was more active than those of induced triploid far eastern catfish in each tissue, and mitosis of gill tissue in each ploidy was more active than those of tail fin tissue in each ploidy. Merely, diploid and induced triploid far eastern catfish using this experiment was 3 years after hatched, and the measured time was spawning season, when diploid had matured gonad but induced triploid had maintained sterility of a gonad. Therefore, diploid had a higher metabolism and respiratory function than induced triploid (Seol et al., 2008).

The most common application of flowcytometric techniques related to the cell cycle is the determination of the fraction of cells in the gap $1\left(\mathrm{G}_{1}\right)$-, synthesis (S)-, and gap $2\left(\mathrm{G}_{2}\right)+$ mitosis $(\mathrm{M})$-phases (Dean and Jett, 1974). This information is obtained from DNA distributions. In each distribution, the peak at $\times 1$ DNA content (relative fluorescence, 50 ) is produced by diploid, $\mathrm{G}_{1}$-phase cells. The peak at $\times 2$ DNA content (relative fluorescence, 100) is produced by $\mathrm{G}_{2}+\mathrm{M}$ phase cells, and the intermediate continuum is produced by S-phase cells in which varying amounts of DNA have replicated. The areas under each of these regions of DNA distribution are proportional to the fractions of cells in the corresponding cell cycle phase (Dean \& Jett, 1974). As mentioned Xoana et al. (2012), cyclin D1 and 
cyclin E are related to cell division and DNA synthesis. If protein expressions of cyclin D1 and cyclin E are higher, then cell cycle is shorter. In this study, proteins expressions of both cyclin in diploid were higher than those in induced triploid, and cell cycle of diploid was shorter than that of induced triploid.

Phase fraction analysis can be used in the assessment of cellular growth conditions (Dean \& Jett, 1974). Numerous studies on growth rates of induced triploid fish have been published. Increased cell size does not appear to confer any growth advantage to induced triploids, due to the concomitant decrease in cell numbers. The rate of muscle fiber growth does not differ between induced triploids and diploids, whether juvenile or adult (Yamashita, 1993). Reduced gonadal growth in induced triploids may allow increased energy allocation to somatic growth, but any growth advantage may be offset by diminished levels of gonadal steroids, which have an anabolic effect (Benfey, 1999). This study has been able to verify certain factual information, which in conjunction with other characteristics, can be used as indicators in the identification of triploidization and ploidy level in far eastern catfish.

\section{ACKNOWLEDGEMENTS}

We thanks the staff of the Fishery Genetics and Breeding Sciences Laboratory at Korea Maritime and Ocean University, Korea for their assistance with sampling and data acquisition. Comments from anonymous reviewers greatly improved the quality of this manuscript. All experiments in this study complied with the current law of Korea (the law regarding experimental animals, No. 9932).

\section{REFERENCES}

Aliah RS, Yamaoka K, Inada Y and Taniguchi N (1990).

Effects of triploidy on tissue structure of some organs in ayu. Nip Sui Gak 56:569-575.
Allen SK and Jr. Stanley JG (1978). Reproductive sterility in polyploidy brook trout (Salvelinus fontinalis). Trans Amer Fish Soc 107:473-478.

Benfey TJ (1999). The physiology and behavior of triploid fishes. Fish Sci 7:39-67.

Cassani JR, Maloney DR, Allaire HP and Kerby JH (1990). Problems associated with tetraploid induction and survival in grass carp (Ctenopharyngodon idella). Aquaculture 88:273-284.

Choi GC, Kim DS, Jo J-Y and Kim JM (1992). Induced breeding and indoor culture of the catfish (Silurus asotus) (Teleostomi: Siluridae). J Aquaculture 5:117-126.

Dean PN and Jett J (1974). Mathematical analysis of DNA distributions derived from flow microfluorometry. J Cell Biol 60:523-527.

Don J and Avtalion RR (1986). The induction of triploidy in Oreochromis aureus by heat shock. Theor Appl Genet 72:186-192.

Estevam J, Danaee H, Liu R, Ecsedy J, Trepicchio W, Wyant $\mathrm{T}$ (2011) Validation of a flow cytometry based $\mathrm{G}_{2} \mathrm{M}$ delay cell cycle assay for use in evaluating the pharmacodynamic response to Aurora A inhibition. J Immuno Meth 363:135-142.

Hulata G (2001). Genetic manipulation in aquaculture: a review of stock improvement by classical and modern technologies. Genetica 111:155-173.

Kim DS, Cho HJ, Park I-S, Choi GC and Nam YK (2001). Cytogenetic traits and gonad development of induced triploidy in far eastern catfish (Silurus asotus). Gene \& Genomics 23:55-62.

Kim DS, Choi GC and Park I-S (1990). Triploidy production of nile tilapia (Oreochromis niloticus). J Aquaculture 3:135-144.

Kim DS, Jo JY and Lee TY (1994). Induction of triploidy in mud loach (Misgurnus mizolepis) and its effect on gonad development and growth. Aquaculture 120:263270.

Komaru A, Uchimura Y, Ieyama H and Wada KT (1988). 
Detection of induced triploid scallop (Chlamys nobilis) by DNA microflurometry with DAPI staining. Aquaculture 69:201-209.

Maxime V (2008). The physiology of triploid fish: current knowledge and comparisons with diploid fish. Fish Fisher 9:67-78.

Murray JD, Anderson GB, Oberbauer AM and McGloughlin MN (1999). Transgenic animals in agriculture. In Comparison of traditional breeding and transgenesis in farmed fish with implications for growth enhancement and fitness. Dunham R.A., Devlin R.H., Eds., CAB International, New York, NY, U.S.A, pp. 209-229.

Nunez R (2001). DNA measurement and cell cycle analysis by flowcytometry. Curr Issues Mol Biol 3:67.

Park I-S and Kim DS (2000). Comparison of some tissue in diploid and triploid hybrid between mud loach (Misgurnus mizolepis) and cyprinid loach (M. anguillicaudatus). Dev Reprod 4:19-28.

Park I-S and Kim H-B (1994). Induction of triploid cherry salmon (Oncorhynchus masou). J Aquaculture 7:176192.

Park I-S and Park KY (1994). Haematological and physiological characteristics of diploid and triploid in cherry salmon (Oncorhynchus masou). J Aquaculture 7:193201.

Park I-S, Im JH and Hur JW (2004). Morphometric characteristics of catfish (Siluridae) in Korea. Kor J Ichthyol 16:223-228.

Park I-S, Kim CH and Kim DS (1999). Karyotypes and cellular DNA contents of two species in the genus Lateolabrax from Korea. Fish Sci 65:488-489.

Park I-S, Kim H-B, Son JK and Kim DS (1994). Induction of triploid red seabream (Pagrus major). Kor J Ichthyol 6:71-78.

Park I-S, Lee C-K, Im JH, Kim JH and Kim SU (1998). Effect of starvation on the growth and hepatocyte nuclear size of larval rockfish (Sebastes schlegelii) and larval spotted sea bass (Lateolabrax sp.). J Aquaculture
11:345-352.

Phillips RB, Zajicek KD, Ihssen PE and Johnson O (1986). Application of silver staining to the identification of triploid fish cells. Aquaculture 54:313-319.

Seol DW, Im S-Y, Hur JW, Park MO, Kim DS, Jo J-Y and Park I-S (2008). Haematological parameters and respiratory function in diploid and triploid far eastern catfish (Silurus asotus). Genes \& Genomics 30:205-213.

Swarup H (1959). Effect of triploidy on the body size, general organization and cellular structure in Gasterosteus aculeatus. J Genet 56:143-155.

Takashi H (1982). An Altas of Fish Histology. In Sensory Organs. Fumio T., Ed., Kodansha Ltd, Tokyo, Japan, pp. $42-53$.

Tave D (1993). Growth of triploid and diploid bighead carp (Hypophthalmichthys nobilis). J Appl Aquacult 2: 13-25.

Thorgaard GH (1986). Ploidy manipulation and performance. Aquaculture 57:57-64.

Thorgaard GH, Rabinovitch PS, Shen MW, Gall GAE, Propp J and Utter FM (1982). Triploid rainbow trout identified by flow cytometry. Aquaculture 29:305-309.

Tiwary BK, Kirubaran R and Ray AK (2004). The biology of triploid fish. Rev Fish Biol Fish 14:391-402.

Ueno K (1984). Induction of triploid carp and their haematological characteristics. Jpn J Genet 59:585-591.

Vanparys C, Maras M, Lenjou M, Robbens J, Van Bockstaele D, Blust R, De Coen W (2006). Flow cytometric cell cycle analysis allows for rapid screening of estrogenicity in MCF-7 breast cancer cells. Toxicol in Vitro 20:1238-1248.

Wolters WR, Chrisman CL and Libey GS (1982). Erythrocyte nuclear measurements of diploid and triploid channel catfish, Ictalurus punctatus (Rafinicsque). J Fish Biol 20:253-258.

Xoana T, Diego R, Lorena DP, Antonio R, Alicia F, Paulino $M$ and Ana V (2012). Comparative expression analysis in mature gonads, liver and brain of turbot (Scoph- 
HW Gil, TH Lee, HJ Han, I-S Park

thalmus maximus) by cDNA-AFLPS. Gene 492:250261.

Yamashita Y (1993). Histological change in the muscles of diploid and triploid ayu during growth and maturation. Bull JPN Soc Sci Fish 59:1,151-1,154.
Yang WS, Gil HY, Yoo GW and Park I-S (2015). Identification of skeletal deformities in far eastern Catfish, $\mathrm{Si}$ lurus asotus under indoor aquaculture condition. Dev Reprod 3:153-161. 